\title{
Nomenclature changes in the flatworms (Platyhelminthes)
}

\author{
Filippo Ceccolini ${ }^{1}$, Fabio Cianferoni ${ }^{2,1^{*}}$
}

\begin{abstract}
${ }^{1}$ Zoology, "La Specola", Natural History Museum, University of Florence, Via Romana 17, I-50125 Florence, Italy.E-mail: ceccolinif@virgilio.it; ORCID: 0000-0002-1476-914X

${ }^{2}$ Research Institute on Terrestrial Ecosystems (IRET), National Research Council of Italy (CNR), Via Madonna del Piano 10, I-50019 Sesto Fiorentino (Florence), Italy. E-mail: fabio.cianferoni@cnr.it; ORCID:0000-0003-3170-0774

* Corresponding Author
\end{abstract}

ABSTRACT: Four junior homonyms were detected amongst the genera of Platyhelminthes and the following replacement names are proposed: Emprostiotrema Cianferoni et Ceccolini nom.n. pro Atractotrema Goto et Ozaki, 1929 nec Cossmann, 1888 and consequently the new family name Emprostiotrematidae Cianferoni et Ceccolini nom.n. pro Atractotrematidae Yamaguti, 1939; Aristeraclelandia Ceccolini et Cianferoni nom.n. pro Clelandia Johnston, 1909 nec Cossmann, 1902; Pseudosemenoviella Ceccolini et Cianferoni nom.n. pro Semenoviella Spasskij, 1951 nec Obenberger, 1924; Turdifernandezia Ceccolini et Cianferoni nom.n. pro Fernandezia López-Neyra, 1936 nec Hyatt et Pilsbry, 1911. The genus Opepherotrematoides Yamaguti, 1970 is revalidated. Seven new combinations (comb.n.) are stated.

How to site this article: Ceccolini F., Cianferoni F. 2021. Nomenclature changes in the flatworms (Platyhelminthes) // Invert. Zool. Vol.18. No.4. P.451-456. doi: 10.15298/ invertzool.18.4.02

KEY WORDS: combinatio nova, nomen novum, Platyhelminthes, replacement name, resurrected name.

\section{Изменения в номенклатуре плоских червей (Platyhelminthes)}

\section{Филиппо Чекколиниㄹ, Фабио Чианферони²,1*}

\footnotetext{
${ }^{1}$ Zoology, "La Specola", Natural History Museum, University of Florence, Via Romana 17, I-50125 Florence, Italy. E-mail: ceccolinif@virgilio.it; ORCID: 0000-0002-1476-914X

${ }^{2}$ Research Institute on Terrestrial Ecosystems (IRET), National Research Council of Italy (CNR), Via Madonna del Piano 10, I-50019 Sesto Fiorentino (Florence), Italy. E-mail: fabio.cianferoni@cnr.it; ORCID:0000-0003-3170-0774

* Автор, ответственный за переписку
}

РЕЗЮМЕ: Среди родов Platyhelminthes обнаружено четыре младших омонима, в этой связи предлагаются следующие замещающие названия: Emprostiotrema Cianferoni et Ceccolini nom.n. для Atractotrema Goto et Ozaki, 1929 не входившие в состав Cossmann, 1888 и, следовательно, новое название семейства Emprostiotrematidae Cianferoni et Ceccolini nom.n. для Atractotrematidae Yamaguti, 1939; Aristeraclelandia Ceccolini et Cianferoni nom.n. для Clelandia Johnston, 1909, не входившие в состав 
Cossmann, 1902; Pseudosemenoviella Ceccolini et Cianferoni nom.n. для Semenoviella Spasskij, 1951, не входившие в состав Obenberger, 1924; Turdifernandezia Ceccolini et Cianferoni nom.n. для Fernandezia Lypez-Neyra, 1936 не входившие в состав Нyatt et Pilsbry, 1911. Род Opepherotrematoides Yamaguti, 1970 повторно валидирован. Заявлено семь новых комбинаций (comb.n.).

Как цитировать эту статью: Ceccolini F., Cianferoni F. 2021. Nomenclature changes in the flatworms (Platyhelminthes) // Invert. Zool. Vol.18. No.4. P.451-456. doi: 10.15298/ invertzool.18.4.02

КЛЮЧЕВЫЕ СЛОВА: новая комбинация (combinatio nova), новое имя (nomen novum), Platyhelminthes, заменяющее имя (replacement name), воскрешённое имя (resurrected name).

\section{Introduction}

Platyhelminthes Claus, 1887 (for the choice of the correct spelling see Ehlers, Sopott-Ehlers, 1995 ) is a large phylum including about 30000 species (Zhang, 2013). It has been recently revised, removing from it the species currently considered belonging to the phylum Xenacoelomorpha Philippe et al., 2011 (see Egger et al., 2009; Philippe et al., 2011). Within Platyhelminthes there are several genera whose names are junior homonyms, not recognized as such thus far. Therefore, according to the International Code ofZoological Nomenclature (ICZN, 1999), new replacement names are needed for them. The following new names proposed in this work allow to solve in part the confusion between the nomenclature of platyhelminths and other zoological groups.

The platyhelminth classification adopted is mainly in agreement with Egger et al. (2015) and Tyler et al. (2006-2021).

\section{Systematic part}

\section{Replacement names}

I.

\section{Subphylum RHABDITOPHORA} Ehlers, 1985

Class TREMATODA Rudolphi, 1808

Order PLAGIORCHIIDA La Rue, 1957

Family ATRACTOTREMATIDAE

Yamaguti, 1939 (to be replaced, see below)

In his work about Eocene molluscs Cossmann (1888: 31) established the name Atrac- totrema as "new section" of Fissurella Bruguière, 1789; currently the name is an accepted genus of Gastropoda Fissurellidae (Molluscabase, 2021).

More than 40 years later, Goto \& Ozaki (1929: 370) used the same name for a genus of flatworm, currently still accepted (Bakhoum et al., 2015; Tyler et al., 2006-2021). Thus, the genus Atractotrema Goto et Ozaki, 1929 is a junior homonym of the genus name Atractotrema Cossmann and, according to the ICZN (1999, Article 60), since no synonyms are available (see ICZN, 1999, Arts. 60.1, 60.2), it should be replaced with a new name. Herein we propose the name Emprostiotrema Cianferoni et Ceccolini nom.n.

ETYMOLOGY. The new name, from $\dot{\varepsilon} \mu \pi \rho \operatorname{có} \theta \mathrm{to} \varsigma$ (anterior), refers to the position of the male gonopore. Neutral gender.

\section{SYSTEMATICS}

Genus Emprostiotrema Cianferoni et Ceccolini nom.n.

Species Emprostiotrema fusum (Goto et Ozaki, 1929) comb.n. = Atractotrema fusum Goto et Ozaki, 1929 (type species)

Emprostiotrema kuntzi (Ahmad, 1985) comb.n. = Atractotrema kuntzi Ahmad, 1985

Emprostiotrema sigani (Durio et Manter, 1969) comb.n. $=$ Atractotrema sigani Durio et Manter, 1969

REMARKS. Atractotrema Goto et Ozaki, 1929 is the type genus of the family Atractotrematidae, thus the name of this family-group taxon is invalid because its type genus is a junior homonym (ICZN, 1999, Arts. 23.4.1,39). Since no synonyms are available, a replacement for 
the family-group name is required in relation to the new generic name. We propose Emprostiotrematidae Cianferoni et Ceccolini nom.n. to replace Atractotrematidae Yamaguti, 1939.

II.

\section{Subphylum RHABDITOPHORA Ehlers, 1985}

Class CESTODA Rudolphi, 1808

Order CYCLOPHYLLIDEA van Beneden in Braun, 1900

Family DILEPIDIDAE Fuhrmann, 1907

Cossmann (1902: 52) proposed the name Clelandia as nomen novum for the preoccupied trilobite name Harrisia Cleland, 1900 nec Harrisia Robineau-Desvoidy, 1830 (Diptera); currently the name is an accepted genus of Ptychopariida Kingstoniidae (Jell, Adrain, 2013; IRMNG, 2021).

Few years later, Johnston (1909: 145) erected the new genus Clelandia for the new Cestoda species $C$. parva; so far this genus name is accepted (see Bona, 1978; Presswell et al., 2012; Mariaux et al., 2017; IRMNG, 2021). However, this name is invalid under the principle of homonymy, being a junior homonym of Clelandia Cossmann. It lacks an available synonym (see ICZN, 1999, Arts. 60.1, 60.2); thus, we propose to replace it with the name Aristeraclelandia Ceccolini et Cianferoni nom.n.

ETYMOLOGY. The new name, ỏpı $\tau \varepsilon \rho \alpha ́$ (left), refers to the position of the gonopores. Feminine gender.

SYSTEMATICS

Genus Aristeraclelandia Ceccolini et Cianferoni nom.n.

Species Aristeraclelandia parva (Johnston, 1909) comb.n. = Clelandia parva Johnston, 1909 (type species)

III.

\section{Subphylum RHABDITOPHORA Ehlers, 1985 \\ Class CESTODA Rudolphi, 1808 \\ Order CYCLOPHYLLIDEA van Beneden in Braun, 1900 \\ Family ANOPLOCEPHALIDAE \\ Cholodkowsky, 1902}

Lühe (1898: 650) established the genus Oochoristica for reptile cestodes, including two species precedently described by Rudolphi (1819) under the genus Taenia. One of them was later transferred by Spasskij (1951: 593) to the new genus Semenoviella. Even if Della Santa (1956) considered Semenoviella synonym of Oochoristica, to date the two genera are maintained separated. Indeed, whilst Oochoristica includes about 85 species, even if most of them needs a revision (Schuster, 2011), according to criteria presented by Mašová et al. (2012), Semenoviella accomodates the species $S$. amphisbaenae (Rudolphi, 1819) (Ávila, Silva, 2010; Justo et al., 2017; IRMNG, 2021).

However, Semenoviella Spasskij is invalid as the name is preoccupied by Semenoviella Obenberger, 1924. Indeed, Obenberger (1924: 7) used it for a genus of Coleoptera Buprestidae which is still in use (see Bellamy, 2008; IRMNG, 2021). Thus, as no synonym of Semenoviella Spasskij is available, in accordance with the ICZN (1999, Arts. 60.1, 60.2) we propose the new substitute name Pseudosemenoviella Ceccolini et Cianferoni nom.n.

ETYMOLOGY. The new name is formed by adding the prefix $\psi \varepsilon v \delta \delta^{\prime}($ false) to the original name by Spasskij (1951). Feminine gender.

SYSTEMATICS

Genus Pseudosemenoviella Ceccolini et Cianferoni nom.n.

Species Pseudosemenoviella amphisbaenae (Rudolphi, 1819) comb.n. = Semenoviella amphisbaenae (Rudolphi, 1819) = Oochoristica amphisbaenae (Rudolphi, 1819) = Taenia amphisbaenae Rudolphi, 1819 (type species)

IV.

Subphylum RHABDITOPHORA Ehlers, 1985

Class CESTODA Rudolphi, 1808

Order CYCLOPHYLLIDEA van Beneden

in Braun, 1900

Family DAVAINEIDAE Braun, 1900

Hyatt \& Pilsbry (1911: 93) established the genus Fernandezia within the family Achatinellidae. Currently this genus name is still accepted 
within this family of Gastropoda Stylommatophora (MolluscaBase, 2021).

López-Neyra (1936: 16) created a homonym by introducing a new genus to accommodate a new species of cestodes ( $F$. goizuetai) while at the same time transferring to it Davainea spinosissima von Linstow, 1893. Nowadays, Fernandezia López-Neyra is accepted (Mariaux et al., 2017), including three species of parasites of passerine birds according to Schmidt (1986), but only F. goizuetai according to IRMNG (2021). Anyway, Fernandezia López-Neyra is invalid and, lacking available synonyms, according to the ICZN (1999, Arts. 60.1, 60.2), needs a new replacement name which is proposed herein: Turdifernandezia Ceccolini et Cianferoni nom.n.

ETYMOLOGY. The new name refers to the host, belonging the bird genus Turdus, from which the type specimens were collected (López-Neyra 1936: 16), adding the stem of the genus as prefix and a "i" as connection. Feminine gender.

\section{SYSTEMATICS}

Genus Turdifernandezia Ceccolini et Cianferoni nom.n.

Species Turdifernandezia goizuetai (LópezNeyra, 1936) comb.n. = Fernandezia goizuetai López-Neyra, 1936 (type species)

\section{Resurrected name}

\section{Subphylum RHABDITOPHORA Ehlers, 1985}

Class TREMATODA Rudolphi, 1808

Order PLAGIORCHIIDA La Rue, 1957 Family DIDYMOZOIDAE Monticelli, 1888

Mamaev (1968: 166) established the genus Didymosphaera within the fluke family Didymozoidae to accommodate the new species D. mirabilis. Pozdnyakov $(1993,1996)$ synonymized Opepherotrematoides and Triplocystoides Yamaguti, 1970 with Didymosphaera. Currently, the genus Didymosphaera includes three species: D. mirabilis Mamaev, 1968, D. multitubularis (Yamaguti, 1970), and D. yaito (Yamaguti, 1970) (Tyler et al., 2006-2021).
However, previously Linck (1883: 59) had named Didymosphaera a genus of fossil Demospongea, currently still accepted (Sepkoski, 2002; IRMNG, 2021). Consequently, Didymosphaera Mamaev is a junior homonym and needs to be replaced (ICZN, 1999, Art. 60.1). In this case the genus has two junior subjective synonyms and according to Art. 60.2 of ICZN (1999) the oldest of these becomes the valid name of the taxon. Both Opepherotrematoides and Triplocystoides were established by Yamaguti (1970); Opepherotrematoides was introduced on page 214 and Triplocystoides on page 215. Here, acting as First Revisers (see ICZN, 1999, Art. 24.2.1), we choose the first name that appears in the publication that is Opepherotrematoides Yamaguti, 1970 to replace Didymosphaera Mamaev, 1968.

SYSTEMATICS 1970

Genus Opepherotrematoides Yamaguti,

Species Opepherotrematoides mirabilis (Mamaev, 1968) = Didymosphaera mirabilis Mamaev, 1968

Opepherotrematoides multitubularis Yamaguti, 1970 (type species) = Didymosphaera multitubularis (Mamaev, 1968)

Opepherotrematoides yaito (Yamaguti, 1970) comb.n. = Didymosphaera yaito (Yamaguti, 1970) $=$ Triplocystoides yaito Yamaguti, 1970

Acknowledgments. Thanks are due to Alberto Ballerio (ICZN - International Commission on Zoological Nomenclature) for a useful clarification regarding an article of the Code. We also thank the two anonymous reviewers for their useful comments and suggestions on the manuscript.

\section{References}

Ávila R.W., Silva R.J. 2010. Checklist of helminths from lizards and amphisbaenians (Reptilia, Squamata) of South America // The Journal of Venomous Animals and Toxins including Tropical Diseases. Vol.16. No.4. P.543-572. https://doi.org/10.1590/S167891992010000400005

Bakhoum A.J.S., Quilichini Y., Justine J.-L., Bray R.A., Miquel J., Feliu C., Bâ T.C., Marchand B. 2015. First 
spermatological study in the Atractotrematidae (Digenea, Haploporoidea): the case of Atractotrema sigani, intestinal parasite of Siganus lineatus // Parasite. Vol.22. No.26. https://doi.org/10.1051/parasite/ 2015026 [10 p.].

Bellamy C.L. 2008. A World Catalogue and Bibliography of the Jewel Beetles (Coleoptera: Buprestoidea), Volume 2: Chrysochroinae: Sphenopterini through Buprestinae: Stigmoderini. Sofia: Pensoft Series Faunistica. No.77. P.626-1259.

Bona F.V. 1978. The genus Clelandia Johnston, 1909 and its affinities with Parvitaenia and Neogryporhynchus (Cestoda, Dilepididae) // Annales de Parasitologie. Vol.53. No.2. P.163-180. https://doi.org/10.1051/ parasite/1978532163

Cossmann M. 1888. Catalogue illustré des coquilles fossiles de l'Éocène des environs de Paris // Annales de la Société royale malacologique de Belgique. Vol.23. P.3-324.

Cossmann M. 1902. Rectifications de nomenclature // Revue critique de Paléozoologie. Vol.6. P.52.

Della Santa E. 1956. Revision du genre Oochoristica Liihe (Cestodes) // Revue Suisse de Zoologie. T.63. Fasc.1. P.1-113.

Egger B., Steinke D., Tarui H., De Mulder K., Arendt D., Borgonie G., Funayama N., Gschwentner R., Hartenstein V., Hobmayer B., Hooge M., Hrouda M., Ishida S., Kobayashi C., Kuales G., Nishimura O., Pfister D., Rieger R., Salvenmoser W., Smith J., Technau U., Tyler S., Agata K., Salzburger W., Ladurner P. 2009. To be or not to be a flatworm: The acoel controversy // PLoS ONE. Vol.4 No.5. e5502. https://doi.org/ 10.1371/journal.pone.0005502 [10 pp.]

Egger B., Lapraz F., Tomiczek B., Müller S., Dessimoz D., Girstmair J., Škunca N., Rawlinson K.A., Cameron C.B., Beli E., Todaro M.A., Gammoudi M., Noreña C., Telford M.J. 2015. A Transcriptomic-Phylogenomic Analysis of the Evolutionary Relationships of Flatworms // Current Biology. Vol.25. No.10. P.13471353. https://doi.org/10.1016/j.cub.2015.03.034

Ehlers U., Sopott-Ehlers B. 1995. Plathelminthes or Platyhelminthes? // Cannon L.R.G. (ed.). Biology of Turbellaria and some Related Flatworms // Hydrobiologia. Vol.305. P.1-2. https://doi.org/10.1007/978-94011-0045-8_1

Goto S., Ozaki Y. 1929. Brief notes on new trematodes II // Japanese Journal of Zoology. Vol.2. P.369-383.

Hyatt A., Pilsbry H.A. 1911. Manual of conchology, structural and systematic, with illustrations of the species. Ser. 2, Pulmonata. Vol. 21: Achatinellidae (Amastrinae). Philadelphia: Conchological Department, Academy of Natural Sciences. XXII + 387 p. +56 tavv.

ICZN. 1999. International Code of Zoological Nomenclature. 4th Edition. London: The International Trust for Zoological Nomenclature, XXIX + 306 p.

IRMNG. The Interim Register of Marine and Nonmarine Genera 2021. Available from: https://www.irmng.org at VLIZ. [Last accessed 7 june 2021]

Jell P.A., Adrain J.M. 2003. Available generic names for trilobites // Memoirs of the Queensland Museum.
Vol.48(2002). No.2. P.331-353.

Johnston T.H. 1909. On a new genus of Bird-Cestodes // Journal and Proceedings of the Royal Society of New South Wales. Vol.43. P.139-147.

Justo M.C.N., Fernandes B.M.M., Knoff M., Cárdenas M.Q., Cohen S.C. 2017. Checklist of brazilian Cestoda//Neotropical Helminthology. Vol.11. No.1.P.187282.

Linck G. 1883. Zwei neue Spongiengattungen // Neues Jahrbuch für Mineralogie, Geognosie, Geologie und Petrefaktenkunde. Bd.2. S.59-62 + Tavv. 2,3.

López-Neyra C.R. 1936. "Fernandezzia [sic!] goizuetai nov. gen. nov. sp." parasito intestinal del zorzal y revisión de los "Ophryocotylinae" // Revista de la Real Academia de Ciìncias Exactas Físicas y Naturales de Madrid. Vol.33. No.1. P.5-18.

Lühe M. 1898 Oochoristica nov. gen. Taeniadarum // Zoologischer Anzeiger. Bd.21. Nr.549-576. S.50652.

Mamaev Y.L. 1968. [Didymosphaera mirabilis gen. et sp. nov. (Didymozoidae) a trematode from the body of tuna] // Parazitologiya. Vol.2. P.159-166 [in Russian].

Mariaux J., Tkach V.V., Vasileva G.P., Waeschenbach A., Beveridge I., Dimitrova Y.D., Haukisalmi V. Greiman S.E., Timothy D., Littlewood J., Makarikov A.A., Phillips A.J., Razafiarisolo T., Widmer V., Georgiev B.B. 2017. Cyclophyllidea van Beneden in Braun, 1900 // Caira J.N., Jensen K. (eds). Planetary Biodiversity Inventory (2008-2017): Tapeworms from Vertebrate Bowels of the Earth. Lawrence, Kansas: University of Kansas, Natural History Museum, Special Publication No. 25. P.77-148.

Mašová Š., Tenora F., Baruš V. 2012. Oochoristica koube$k i$ n. sp. (Cestoda, Anoplocephalidae) from African Chamaeleo senegalensis (Chamaeleonidae) and emendation of the genus Oochoristica Lühe, 1898 // Helminthologia. Vol.49. No.1. P.27-32. https://doi.org/ 10.2478/s11687-012-0005-2

MolluscaBase (eds.). 2021. MolluscaBase. Available from: http://www.molluscabase.org [last accessed on 29 April 2021]. https://doi.org/10.14284/448

Obenberger J. 1924. Deuxième série de noveaux genres de Buprestides // Sborník entomologického oddilení Národního Musea v Praze. Vol.2. No.12. P.7-44.

Papavero N. 2008. Catalogue of Neotropical Diptera. Asilidae // Neotropical Diptera. Vol.17. P.1-178.

Philippe H., Brinkmann H., Copley R.R., Moroz L.L., Nakano H., Poustka A.J., Wallberg A., Peterson K.J., Telford M.J. 2011. Acoelomorph flatworms are deuterostomes related to Xenoturbella // Nature. Vol.470. No.7333. P.255-260. https://doi.org/10.1038/nature 09676

Pozdnyakov S.E. 1993. [System of Trematodes of the suborder Didymozoata]//Parazitologiya. Vol.27. No.6. P.415-425 [in Russian].

Pozdnyakov S.E. 1996. [Trematode suborder Didymozoata]. Vladivostok: Tikhookeanskii Naucho-Issledovatel'skii Rybokhozyaistvennyi Tsentr Vladivostok. 319 p. [In Russian] 
Preswell B., Poulin R., Randhawa H.S. 2012. First report of a gryporhynchid tapeworm (Cestoda: Cyclophyllidea) from New Zealand and from an eleotrid fish, described from metacestodes and in vitro-grown worms // Journal of Helminthology. Vol.86. No.4. P.453464. https://doi.org/10.1017/S0022149X11000691

Rudolphi C.A. 1819. Entozoorum synopsis cui accedunt mantissa duplex et indices locupletissimi. Berlin: A. Rückeri. 811 p.

Schmidt G.D. 1986. Handbook of Tapeworm identification. Boca Raton, Florida: CRC Press. 675 p.

Schuster R.K. 2011. Oochoristica chalcidesi n. sp. (Eucestoda: Linstowiidae) from the ocellated skink, Chalcides ocellatus (Forskal, 1775) in the United Arab Emirates // Journal of Helminthology. Vol.85. No.4. P.468-471. S0022149X10000842

Sepkoski J.J. 2002. A compendium of fossil marine animal genera// Bulletins of American Paleontology. Vol.363. P.1-560.
Spasskij A.A. 1951. [Essentials of cestodology. Vol.1. Anoplocephalata - tapeworms of farm and wild animals]. Moscow: AN SSSR Publ. 735 p. [In Russian] Tyler S., Artois T., Schilling S., Hooge M., Bush L.F. (eds.). 2006-2021. World List of turbellarian worms: Acoelomorpha, Catenulida, Rhabditophora. Accessed through: World Register of Marine Species. http:// www.marinespecies.org/turbellarians [last accessed on 7 june 2021]

Yamaguti S. 1970. Digenetic trematodes of Hawaiian fishes. Tokyo: Keigaku. 436 p.

Zhang Z.-Q. 2013. Animal biodiversity: An update of classification and diversity in 2013 // Zhang Z.-Q. (ed.). Animal Biodiversity: An Outline of Higherlevel Classification and Survey of Taxonomic Richness (Addenda 2013) // Zootaxa. Vol.3703. No.1. P.5-11. https://doi.org/10.11646/zootaxa.3703.1.3

Responsible editor N.M. Biserova 